A JOURNAL OF ROMANO-BRITISH \& KINDRED STUDIES

\title{
BRITANNIA
}

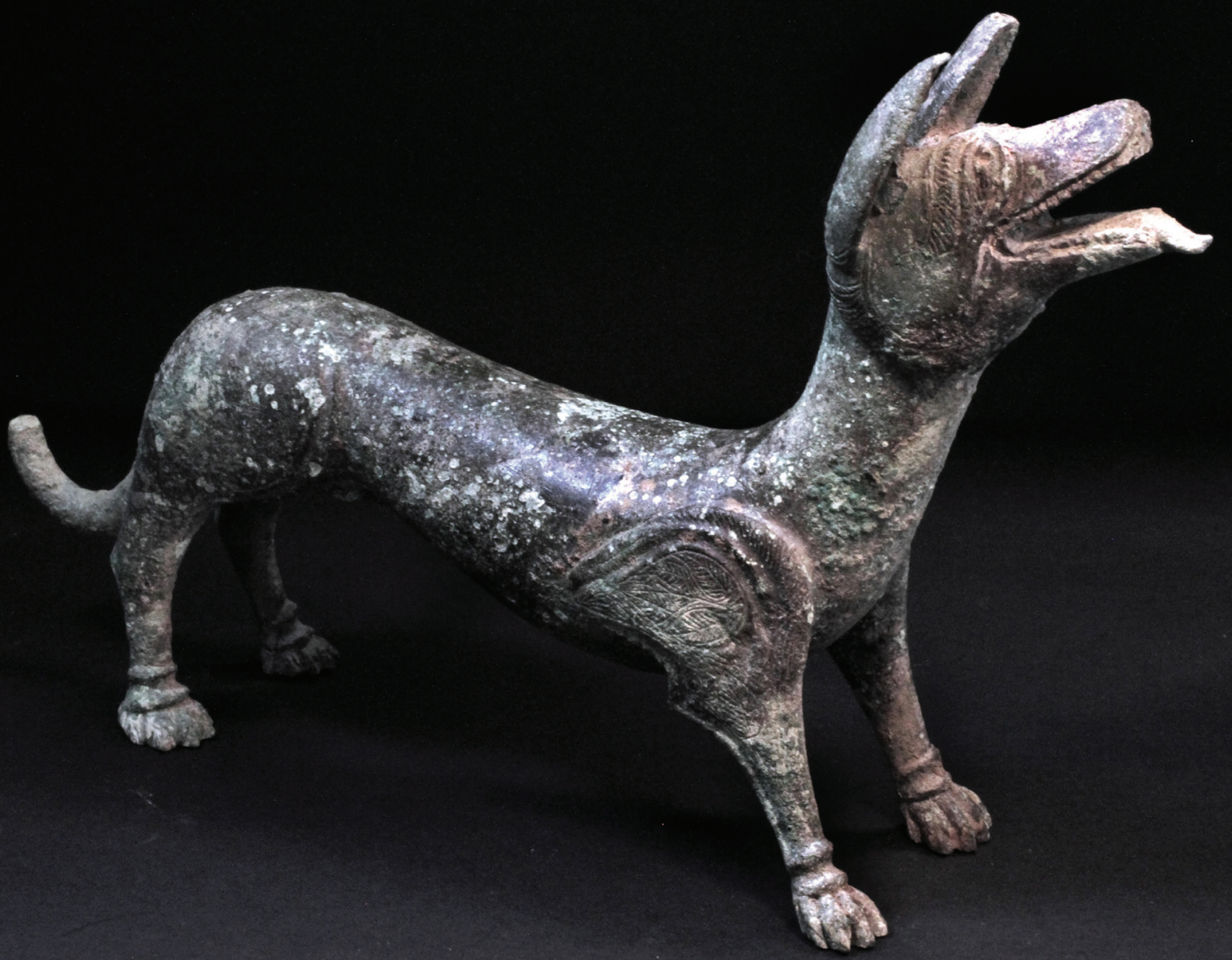

VOLUME $51 \mid 2020$

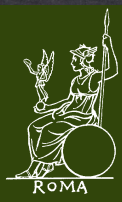

THE SOCIETY FOR THE PROMOTION OF ROMAN STUDIES 
With almost 2,000 members worldwide, the Society is the leading organisation in the United Kingdom for those interested in the study of Rome and the Roman Empire.

THE SOCIETY FOR THE PROMOTION OF ROMAN STUDIES
Its scope is wide, covering Roman history, archaeology, literature and art down to about A.D. 700.

\section{THE SOCIETY SUPPORTS}

- an extensive programme of publication:

- two annual publications - the Journal of Roman Studies, which contains articles and book reviews dealing with the Roman world in general, and Britannia, which has articles and reviews specifically on Roman Britain

- two monograph series - the JRS and Britannia monographs

- an e-newsletter - Epistula - which is circulated twice a year, keeping members up to date with news of recent discoveries, research, exhibitions, conferences and publications

- a library of over I 50,000 volumes, including 700 current periodical titles, maintained jointly with the Hellenic Society and in conjunction with the University of London's Institute of Classical Studies. It has an international reputation as one of the world's foremost Classics lending libraries. It also houses a lending collection of over 6,700 slides

- a programme of public lectures and conferences, visits to sites and museums, and lectures arranged with local branches of the Classical Association

- schools, by the award of grants to help the teaching of all aspects of the Roman world

- university students, by the award of summer placement bursaries at museums and heritage organisations

- archaeology, through grants for excavations and bursaries to sixth-formers for archaeological fieldwork

- conferences, including the international biennial Roman Archaeology Conference

- a website, providing information about the Society, links to other useful sites, and hosting IMAGO, the Society's online image bank developed from the Library slide collection

\section{MEMBERSHIP}

Membership is open to all; no entrance fee or professional qualification is required.

Members are entitled to:

- receive annually in print form and via online access either the JRS or Britannia or both (student members receive their journal(s) online only)

- receive (by email) the biannual e-newsletter

- receive advance notice of forthcoming monographs at special-offer prices

- use the library and borrow the Society's books and slides, either in person or by post, while living or resident in the UK

- attend the Society's lectures and other events, of which a programme is circulated in September

\section{Membership Rates}

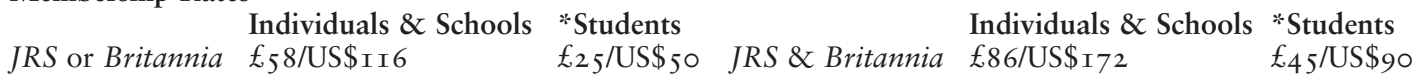

A discounted rate of $£ 57$ for one journal and $£ 84$ for both is available to individual members who pay by direct debit.

*Student membership is open to students registered at any institution of higher education in any country.

Life membership is open to individual members of five years' standing aged 65 or over, at a cost of $£_{45}$ o/US\$900.

For further details contact:

The Secretary, Roman Society, Senate House, Malet Street, London WCiE ${ }_{7} \mathrm{HU}$

Tel.: +44 (o) $20-78628727$

Email: office@romansociety.org

Website: www.romansociety.org

\section{Institutional subscription rates}

Britannia (ISSN 0068 - I $33 \mathrm{X}$ ) is published once a year in November. The subscription price (excluding VAT) of volume 5I (2020), which includes print and electronic access, is $£_{I 77}$ net (US\$334 in the USA, Canada and Mexico) for institutions. EU subscribers (outside the UK) who are not registered for VAT should add VAT at their country's rate. VAT-registered customers should provide their VAT registration number. Japanese prices for institutions (including ASP delivery) are available from Kinokuniya Company Ltd., P.O. Box 55, Chitose, Tokyo I 56, Japan. Prices include delivery by air where appropriate. Orders, which must be accompanied by payment, may be sent to a bookseller, subscription agent or direct to the publisher: Cambridge University Press, Journals Fulfilment Department, UPH, Shaftesbury Road, Cambridge CB2 8BS, UK; or in the USA, Canada and Mexico: Cambridge University Press, I Liberty Plaza, Floor 20, New York, NY I0006, USA. 


\section{BRITANNIA}

A JOURNAL OF ROMANO-BRITISH AND KINDRED STUDIES

VOLUME $51 \mid 2020$

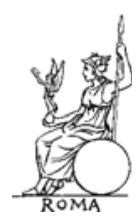

THE SOCIETY FOR

THE PROMOTION OF

ROMAN STUDIES

PUBLISHED BY CAMBRIDGE UNIVERSITY PRESS FOR THE SOCIETY FOR THE PROMOTION OF ROMAN STUDIES, SENATE HOUSE, MALET STREET, LONDON WC1E 7HU 
The Council of the Society desires to record its gratitude for a generous grant towards the publication of this volume to the following:

The Administrators of the Haverfield Bequest

Cover image:

Gloucester: hound statuette

See Penny Coombe and Martin Henig, 'The Gloucester hoard of Roman Bronze', 225-264

(C) The Society for the Promotion of Roman Studies

ISSN 0068-113X (Print)

ISSN 1753-5352 (Online)

Typeset by Techset Composition Ltd, Salisbury, UK

Printed in Great Britain by Bell \& Bain Ltd, Glasgow 


\section{CONTENTS}

vii NOTES FOR CONTRIBUTORS

1-5 EDITORIAL

\section{ARTICLES}

7-52 tatiana IVleva, The Origin of Romano-British Glass Bangles: Forgotten Artefacts from the Late Pre-Roman Iron Age

53-82 ADAm SutTon, Resistance is Futile? Ceramic Technology and Social Change in Later Iron Age and Early Roman Britain: Silchester Ware as a Case Study

83-116 HANNAH J. O'REgAN, KEITH BLAND, JANE EVANS, MATILDA HOLMES, KIRSTY MCLEOD, ROBERT PHILPOTT, IAN SMITH, JOHN THORP AND DAVID M. WILKINSON, Rural Life, Roman Ways? Examination of Late Iron Age to Late Romano-British Burial Practice and Mobility at Dog Hole Cave, Cumbria

117-145 TOBY G. DRIVER, BARRY C. BURNHAM AND JEFFREY L. DAVIES, Roman Wales: Aerial Discoveries and New Observations from the Drought of 2018

147-174 TONY wilmott AND PHilip SMither, The Plan of the Saxon Shore Fort at Richborough

175-201 Louisa CAmpbell, Polychromy on the Antonine Wall Distance Sculptures: Nondestructive Identification of Pigments on Roman Reliefs

203-223 w.s. HANson, The Design of the Antonine Wall

225-264 PENNy COOMbe AND MARTIN Henig, The Gloucester Hoard of Roman Bronze

265-294 NICO ROYMANS, TON DERKS AND STIJN HEEREN, Roman Imperialism and the Transformation of Rural Society in a Frontier Province: Diversifying the Narrative

295-306 michael fulford, The Countryside of Roman Britain: A Gallic Perspective

\section{SHORTER CONTRIBUTIONS}

307-317 Dave Stewart, paul cheetham and miles russell, A Magnetometry Survey of the Second Augustan Legionary Fortress at Lake Farm, Dorset

318-323 MARTIN MILLETT AND RICHARD BRICKSTOCK, An Early Roman Fort at Thirkleby, North Yorkshire

323-330 W.S. HANSON AND D.J. BREEZE, Julius Verus and the Abandonment of Antonine Scotland

330-335 JERoen W.P. Wijnendaele, Ammianus, Magnus Maximus and the Gothic Uprising

336-347 RUTH BEVERIDGe AND TOM woolhouse, An Unusual Imported Bronze Jug Handle from Late Iron Age Easton, Suffolk

348-360 PETER WARRY, The Quantification and Interpretation of Ceramic Building Material (CBM) Assemblages in Britain

360-375 PAul EVERSON AND DAVID STOCKer, The Romano-British 'Aedicule' from Sheepwash Grange, Canwick, Lincolnshire

376-387 NINA CRUMmy AND GLYNN J.C. DAvis, A Black Mineral Amulet from Colchester's North Cemetery 


\section{ROMAN BRITAIN IN 2019}

389-439 I. Sites Explored by Evan M. Chapman, Fraser Hunter, Rob Collins, Alice Lyons, Sadie Watson and John P. Salvatore

441-470 II. Finds Reported under the Portable Antiquities Scheme by John Pearce and Sally Worrell

471-525 III. Inscriptions by R.S.O. Tomlin

\section{REVIEWS}

527-529 Anthony, v., R. AbDy And s. Clews (eds), The Beau Street, Bath Hoard and Bland, R., Coin Hoards and Hoarding in Roman Britain A.D. 43 - c.498 (by Kris Lockyear)

529-530 Allison, P., M. PITTS AND S. COlley, Big Data on the Roman Table: New Approaches to Tablewares in the Roman World (by Jane Timby)

530-531 ANELAY, G., with contributions from M. ALLEN, M. BISHOP, D. BONE, N. HASKINS, J. KENNY, M. LEWIS, A. PAYNe, C. POOLE, J. TIMBy AND M. VITOLO, The Selhurst Park Project, Middle Barn, Selhurstpark Farm, Eartham, West Sussex 2005-2008 (by David Rudling)

531-532 BIDWELL, P., Hadrian's Wall at Wallsend (by Tony Wilmott)

532-533 BREEZE, D., Hadrian's Wall: A Study in Archaeological Exploration and Interpretation (by Marta Alberti)

534-534 BREEZE, DAVID J., Maryport: A Roman Fort and its Community (by Matthew Symonds)

535-536 ECKARDT, H., Writing and Power in the Roman World: Literacies and Material Culture (by Anna Willi)

536-537 Esposito, A., Performing the Sacra: Priestly Roles and their Organisation in Roman Britain (by Martin Henig)

537-538 FitZPATrick, A.P. AND C. HASElgrove (eds), Julius Caesar's Battle for Gaul: New Archaeological Perspectives (by Anna H. Walas)

538-539 Fulford, M., A. Clarke, E. Durham and n. PANKhurst, Late Iron Age Calleva: The Pre-Conquest Occupation at Silchester Insula IX (Silchester Roman Town: The Insula IX Town Life Project 3) (by Manuel Fernández-Götz)

540-541 GONZÁlez SÁNCHEZ, s. AND A. GUglielmi (eds), Romans and Barbarians Beyond the Frontiers: Archaeology, Ideology and Identities in the North (by Fraser Hunter)

541-542 Hingley, R., Londinium: A Biography. Roman London from its Origins to the Fifth Century (by Michael Marshall)

542-543 JONES, A.M., with contributions by R.P. SMITH, D. CHALLINOR, J. JONES, G. KIRHAM, A. LAWSON-JONES, H. QUINNELL AND R. TAYLOR, Excavations of Later Prehistoric and Roman Sites along the Route of the Newquay Strategic Road Corridor, Cornwall (by Chris Smart)

543-544 MACKenZIE, C.K., Culture and Society at Lullingstone Roman Villa (by Simon Esmonde Cleary)

544-545 mason, C., A Romano-British Roadside Settlement at Beanacre, Wiltshire (by Neil Holbrook)

545-546 PARKer, A., AND S. MCKIE (eds), Material Approaches to Roman Magic: Occult Objects and Supernatural Substances (by Natasha Harlow)

546-547 RIPpon, s., Kingdom, Civitas, and County: The Evolution of Territorial Identity in the English Landscape (by William Bowden) 
547-550 Smith, A., M. Allen, T. BRINDle AND M. FUlford, The Rural Settlement of Roman Britain (New Visions of the Countryside of Roman Britain 1), ALLEN, M., L. LODWICK, T. BRINDLE, M. FULFORD AND A. SMITH, with contributions by J. ALLEN, P. BIDWELL, S. RIPPON AND J. TIMBY, The Rural Economy of Roman Britain (New Visions of the Countryside of Roman Britain 2) and SMITH, A., M. ALLEN, T. BRINDLE, M. FULFORD, L. LODWICK AND A. ROHnbogner, Life and Death in the Countryside of Roman Britain (New Visions of the Countryside of Roman Britain 3) (by Stephen L. Dyson)

550-551 TOmlin, R.s.o., Britannia Romana: Roman Inscriptions and Roman Britain (by Alison E. Cooley)

551-552 Zimmermann, M., Romanisation und Repräsentation in Noricum (by Ursula Rothe)

553-555 PROCEEDINGS OF THE SOCIETY FOR THE PROMOTION OF ROMAN STUDIES 2OI9-2O2O 


\section{B RITAN N IA}

\section{NOTES FOR CONTRIBUTORS}

\section{ARTICLES AND SHORTER CONTRIBUTIONS}

1. Articles and shorter contributions should be submitted through the journal's ScholarOne online submission system at https://mc.manuscriptcentral.com/britannia but authors are welcome to discuss their plans in advance with the Editor, Professor Hella Eckardt, Department of Archaeology, University of Reading, Whiteknights, Box 227, Reading RG6 6AB (h.eckardt@reading.ac.uk). All articles and shorter contributions will be peerreviewed anonymously, usually within three months. Articles normally have two reviewers, shorter contributions one, but the number is at the Editor's discretion. Where reviewers disagree in their assessment, the Editor and Editorial Board will make the final decision. Decisions about reviews are made by the Reviews Editor. Detailed comments from referees are normally available to the contributor, anonymously. Papers may be submitted at any time during the year; potential contributors may wish to discuss scheduling with the Editor in advance of submission. In order to protect the interests of authors, the Society requires all authors to sign a form assigning the Society an exclusive licence to publish (not copyright); if a paper includes textual or illustrative material not in the author's copyright, permission must be obtained from the relevant copyright owner for the non-exclusive right to reproduce the material worldwide in all forms and media. Britannia papers are published as Green Open Access; Gold Open Access is available - please discuss your plans with the Editor.

2. Excavation reports will be considered for publication if they are: (a) concise; (b) of national importance and/or offer a significant element of contextualisation and synthesis. Additional parts of the report can be placed online (see 7 below), but the main argument of the report submitted for publication in Britannia should be free-standing and should contain enough information to be coherent without reference to the supplementary material. It is essential that authors discuss proposed contributions with the Editor at an early stage: many excavation reports, even if clearly of national importance, will not be suitable for inclusion in Britannia.

3. The electronic submission system provides further information on the number and format of files to be submitted. Britannia style should be followed, but complex layout should not be attempted. Notes will appear as footnotes but should be presented as endnotes. Tables and figures should be supplied in separate files. Figure and table positions should be highlighted in the text.

4. On final submission papers should be complete in every particular. Every alteration made by an author in proof means higher production costs. The Society retains the right to charge authors for corrections/additions in proof in excess of $£ 1$ a page; the cost of correcting printer's errors does not fall on the Society. All proof corrections and additions are subject to the jurisdiction of the Editorial Board. Cross-references to pages within the article should be avoided. Unless there are exceptional circumstances first proofs only will be submitted to contributors.

5. All articles and shorter contributions should include an abstract (c. 120 and 80 words respectively) and c. 4-8 keywords. For style refer to previous copies of Britannia. Note, the language of publication will normally be English. Publications are to be cited by the author's name and the year of publication followed by the specific page or pages in a numbered footnote (e.g. Jones 1980, 6-9). The full reference to a publication is to be given in an alphabetical bibliography at the end of the paper; journal names should be given in full in the bibliography. Page references should only be given in the footnote if the reference is to a specific page or pages. Full page references of articles etc. should appear in the bibliography (f. and ff. should not be used to indicate following pages). Authors' initials should only appear in the footnotes if the bibliography contains two or more authors with the same surname (e.g. J. Smith 1990). For joint authorship give both names, for multiple authorship Jones et al. is acceptable in the footnotes but all authors should be listed in the bibliography. a, b, c etc. should be used to distinguish several works of the same year (e.g. Smith 1990a). Historical sources should appear in abbreviated form in the footnotes with full references in the bibliography.

6. Illustrations. The type area of a page in Britannia measures 194 by $138 \mathrm{~mm}$. All drawings and photographs should be designed to be reduced to or within such a space. Scales in metres should be provided on plans and be long enough for any likely use. Illustrations do not need to be titled, captions should contain this information. Line artwork should be submitted as tif or eps files at $1200 \mathrm{dpi}$ (black and white for line drawings; grayscale for line/tone). Black and white halftones should be submitted as tifs (greyscale) at a 
minimum 300 dpi. Colour images should be in CMYK colour at a minimum 300 dpi. All electronic artwork should be sized to final publication size; reproduction size should be indicated on a list of the illustrations. For further information on artwork see instructions for authors at www.cambridge.org/core/services/authors/ journals/journals-artwork-guide.

7. Supplementary material (catalogues, tables, illustrations etc.) which supports the article but cannot be included in the print journal for reasons of space may be published online as an attachment to the electronic journal. Any such material must be submitted in the form it is to appear online. For further information see www.romansociety.org/ publications/contributions. Authors planning to submit supplementary material should contact the Editor.

8. Contributors will receive a pdf offprint of their article. Paper offprints will not be provided.

\section{ROMAN BRITAIN IN 20XY}

All contributions should be prepared in accordance with the journal's established style, as set out in the Notes for Contributors for Articles and Shorter Contributions.

(a) Inscriptions

1. This section will be published in its entirety both in the print and online versions of the journal.

2. Information should be sent to Dr R.S.O. Tomlin, Wolfson College, Oxford OX2 6UD (roger.tomlin@wolfson.ox. ac.uk), as soon as the inscribed material is ready for reporting, or at latest before 1 March of the year following discovery. See (b) 6 below for details required.

3. When photographs are taken the light should be raking and, where possible, from the left and well above the horizontal axis.

4. The principles which are followed for the inclusion or exclusion of inscriptions on pottery and tiles are set out in RIB I, p. xvii, s.v. scope (d) 1-4.

(b) Sites Explored

1. This section is intended to incorporate as comprehensive a resume as possible of all work undertaken across Roman Britain in any given year. It will be published in two parts:

i. A selection of the most significant sites and discoveries for each region will be included both in the print and online versions of the journal. Particular emphasis will be placed on entries which have national importance or make a significant contribution to the subject, have accompanying plans and illustrations, and where the findings have ideally been suitably contextualised. The selection of material to be included will be made by the overall editor of the Sites Explored section in consultation with the appropriate regional editor, with reference to the space available in the print journal and the significance of the findings. The selection will also seek to achieve a regional and thematic balance.

ii. All the remaining contributions for each region will only be included in an online file of supplementary material. This is likely to include material from smaller-scale interventions, sites of more regional or local significance, or discoveries of Roman material which testify to Roman-period activity at a specific locality. All the supplementary online material will be in A4 format, with footnotes, and will be accessible via the online-journal webpage.

2. All information about sites and discoveries other than inscriptions or those reported via the Portable Antiquities Scheme should be sent before $\mathbf{3 1}$ March of the year following discovery to:

Wales (Section 1): Mr E. Chapman, Department of Archaeology and Numismatics, National Museum of Wales, Cathays Park, Cardiff CF10 3NP (evan.chapman@museumwales.ac.uk).

Scotland (Section 2): Dr F. Hunter, National Museums of Scotland, Chambers Street, Edinburgh EH1 1JF (f.hunter@nms.ac.uk).

Hadrian's Wall (Section 3) and Northern England (Section 4, which comprises Cheshire, County Durham, Cumbria, Lancashire, Lincolnshire, Northumberland, Yorkshire and associated unitary authorities): Dr Rob Collins, School of History, Classics and Archaeology, Newcastle University, Newcastle upon Tyne NE1 7RU (robert.collins@ newcastle.ac.uk).

The Midlands (Section 5, which comprises Bedfordshire, Buckinghamshire, Cambridgeshire, Derbyshire, Herefordshire, Hertfordshire, Leicestershire, Oxfordshire, Northamptonshire, Nottinghamshire, Rutland, 
Staffordshire, Shropshire, Warwickshire, Worcestershire and associated unitary authorities) and East Anglia (Section 6, which comprises Essex, Norfolk, Suffolk and associated unitary authorities): Alice Lyons, 31 Portersfield Road, Norwich, Norfolk NR2 3JT (alice.lyons1@ntlworld.com).

Greater London (Section 7) and Southern Counties (east) (Section 9b, which comprises Berkshire, East Sussex, Kent, Surrey, West Sussex and associated unitary authorities): Sadie Watson, MoLA, Mortimer Wheeler House, 46 Eagle Wharf Road, London N17ED (swatson@mola.org.uk).

Southern Counties (west) (Section 9a, which comprises Dorset, Hampshire, Isle of Wight, Wiltshire and associated unitary authorities) and South-Western Counties (Section 8, which comprises Cornwall, Devon, Somerset, Gloucestershire and associated unitary authorities): Dr John Salvatore, JPS Heritage Services, Apt. 1, Old St Loyes, Salters Road, Exeter EX2 5SZ (johnpsalvatore@gmail.com).

3. Information on projects including surveys, excavations and evaluations that yield evidence for Roman-period activity is welcomed. Reports should be as concise as is consonant with clarity and comprehensibility, make reference to significant dating evidence and seek to provide an appropriate level of interpretation and contextualisation. They should avoid the level of detail appropriate to an interim or final report, and in all but exceptional circumstances should be less than 1,000 words in length. Negative evidence will not normally be included except where it is relevant to the wider aspects of an otherwise significant site.

4. Where results are particularly significant, or where there is the opportunity to collate the results of several years' work on a long-running investigation which has reached a significant stage or terminated, contributors are also encouraged to contact the Editor at an early stage as the submission of a Shorter Contribution may be deemed advantageous to the readership in advance of final publication (this would allow for accounts of up to 3,500 words). Such contributions will be subject to the normal peer-review process.

5. Plans and other illustrations which enhance understanding of complex and significant investigations are particularly welcomed. It is the responsibility of contributors to ensure that appropriate copyright permissions have been obtained for all illustrations submitted, including those applicable to Ordnance Survey mapping. If a contribution contains illustrative material that is not in the contributor's copyright, permission must be obtained from the relevant copyright owner for the non-exclusive right to reproduce the material worldwide in all forms and media. Illustrations submitted for inclusion in the print journal should conform to the instructions relating to illustrations accompanying Articles and Shorter Contributions.

6. Contributions should be submitted as MS Word-compatible files by email attachment or CD. They should state the county or unitary authority area and, on a separate line, the parish (in bold type), site name (in italic type) and eight-figure National Grid Reference with letter preface (e.g. SU 1830 3915). If the contribution is accompanied by illustrations, captions should be supplied which state the name of the individual or organisation responsible for the illustration and any copyright accreditations. The following details should be included as footnotes:

(a) The name(s) of the individuals responsible for the direction of the investigation (in a commercial environment this might be the Project Officer and/or the Project Manager) and/or for the drafting of the contribution, and, where appropriate, the name of the investigating organisation;

(b) The body funding the investigation (where applicable);

(c) A reference to any previous exploration of the site, where this is directly relevant to the investigation being reported;

(d) Recent and forthcoming publications. Where the investigation is reported in a grey-literature report which is available online, a hyperlink should be included (where possible, a DOI should be cited).

7. Dimensions should be given in Système Internationale units, e.g. metres (m), kilometres (km), hectares (ha), grammes (g). Non-metric equivalents may also be given where useful for comparison with earlier data.

\section{REVIEWS}

The Reviews Editor is Professor Will Bowden (will.bowden@nottingham.ac.uk) and contributions should be sent directly to him. Books for review should be sent to the Librarian, Joint Library, Hellenic and Roman Societies, Senate House, Malet Street, London WC1E 7HU. 


\section{SOCIETY FOR THE PROMOTION OF ROMAN STUDIES}

Company reg. no. 114442. Charity reg. no. 210644

\section{OFFICERS AND COUNCIL 2020-2021}

President: Professor Tim J. Cornell

Vice-Presidents: Professor Catharine H. Edwards Dr Andrew M. Burnett, CBE, FBA, FSA

Professor Dominic W. Rathbone

Elected Members of Council

Elected June 2018

Dr James C. Corke-Webster

Professor Serafina Cuomo

Dr Simon J.J. Corcoran

Dr Sophie Hay

Professor Helen Lovatt

Dr Ross I. Thomas

\author{
Elected June 2019 \\ Dr Siobhan Chomse \\ Dr Ian K.L. Goh \\ Dr Mairéad McAuley \\ Dr Donncha O'Rourke \\ Dr Bobby Xinyue
}

\author{
Elected June 2020 \\ Dr Henriette van der Blom \\ Professor Will Bowden \\ Dr Katharine Earnshaw \\ Dr Penny Goodman \\ Professor Julia Hillner \\ Professor Christian Laes
}

Hon. Treasurer: Dr Philip B. Kay, FSA

Hon. Secretary: Professor Roland G. Mayer

\section{Honorary Vice-Presidents}

Mr Colin H. Annis, MA, ALA

Professor Alan K. Bowman, FBA, FSA

Professor Barry C. Burnham

Professor Dame Averil Cameron, CBE, FBA, FSA

Professor Michael H. Crawford, FBA

Professor A. Simon Esmonde Cleary, FSA

Professor Michael G. Fulford, CBE, FBA, FSA

Professor Atsuko Gotoh

Mr Graham E.A. Kentfield

\section{Honorary Members of the Society}

Dr M. Amandry

Professor R.S. Bagnall

Professor A. Carandini

Professor K.M. Coleman

Professor M. Corbier

Professor H. Cotton

Hon. American Secretary: Professor Glen W. Bowersock

Hon. Librarian: Professor Michael B. Trapp

Librarian: Ms Joanna Ashe

\author{
Journal of Roman Studies Editorial Board \\ Editor: Professor Peter Thonemann \\ Professor Christopher Kelly (JRS 2020) \\ Reviews Editor: Dr Myles Lavan \\ Professor Peter Thonemann (JRS 2020) \\ Dr Henriette van der Blom \\ Professor Barbara E. Borg \\ Professor Julia Hillner \\ Dr Sophie Lunn-Rockliffe \\ Professor Neville Morley \\ Dr Alex Mullen \\ Professor Silvia Orlandi \\ Dr Emily Pillinger \\ Professor Jonathan R.W. Prag \\ Dr Christopher Whitton
}

Secretary: Dr Fiona K. Haarer, FSA

Auditors: Buzzacott LLP

Mr J.H. Colin Leach

Dr Barbara M. Levick, FSA

Dr Joyce M. Reynolds, FBA, FSA

Rev. Professor John S. Richardson, FRSE

Professor Andrew F. Wallace-Hadrill, OBE, FBA, FSA

Professor John J. Wilkes, FBA, FSA

Dr John Peter Wild, FSA

Professor T. Peter Wiseman, FBA, FSA

Professor W. Eck

Professor A.T. Grafton

Professor E.S. Gruen

Professor M. Mayer

Professor P. Zanker

Chair, Roman Studies Committee: Professor Roland G. Mayer Chair, Archaeology Committee: Dr Matthew Symonds Chair, Schools Committee: Dr Clare Harvey

\section{Britannia Editorial Board}

Editor: Professor Hella Eckardt, FSA

Reviews Editors: Professor Will Bowden \&

Dr Natasha Harlow

Mr Paul T. Bidwell, OBE, FSA (Editor, Britannia Monographs)

Dr Martyn Allen

Professor Jen Baird, FSA

Dr Andrew Gardner, FSA

Mr Neil Holbrook, FSA

Dr Lisa Lodwick, FSA

Dr Louise Revell, FSA

Dr Pete Wilson, FSA

Contributions to the JRS should be sent to the Editor, Professor P. Thonemann: peter.thonemann@wadham.ox.ac.uk Contributions to Britannia should be sent to the Editor, Professor H. Eckardt: h.eckardt@reading.ac.uk

Books for review for both the JRS and Britannia must be sent to The Librarian, Joint Library, Hellenic and Roman Societies, Senate House, Malet Street, London WC1E 7HU

(C) Society for the Promotion of Roman Studies 2020. All rights reserved. 